\title{
Effective Professional Development and Change in Practice: The Case of Queen Rania Teacher Academy Science Network
}

\author{
Ahmad Mohammad Qablan 1,2* \\ ${ }^{1}$ Associate Professor in Science Education, Hashemite University, JORDAN \\ ${ }^{2}$ Visiting Professor, University of Alberta, CANADA
}

Received 27 December 2018 - Revised 28 March 2019 • Accepted 27 April 2019

\begin{abstract}
This study aimed at evaluating the impact of Queen Rania Teacher Academy science teachers professional development program's activities on teachers' instructional practices by identifying the successes, challenge and ways to sustain the exemplary reformed instructional practices in the science classroom. The idea is to analyze participating science teachers' reflections on a three-year journey of continuous professional development. Qualitative data collected in the form of participants' selfreflection and field notes from 18 male and female participating science teachers. Findings indicate that even with effective professional development, science teachers encounter diverse challenges to implement the reformed instructional practices in the classroom. Teachers need support, time and resources to succeed in implementing what they learned in their classrooms. Findings also revealed that professional development efforts need to reveal and address existing teachers' beliefs in order to be successful. Implications for future science continuous professional development efforts are discussed.
\end{abstract}

Keywords: science teachers, QRTA, Networks, Jordan

\section{INTRODUCTION}

Continuous Professional development (CPD) programs are considered to be systematic efforts to enhance teachers' classroom instructional practices, their attitudes and beliefs, and enhance students' learning. Shulman $(1986,1987)$ emphasized that teachers are always in need for ongoing professional learning opportunities in order to keep themselves current to perform their complex and challenging job of teaching. To do so, Shulman suggested six domains of knowledge for teachers: subject content knowledge, pedagogical knowledge, pedagogical content knowledge (PCK) (e.g., combining subject matter knowledge with the understanding of how students learn), curricular knowledge (e.g., understanding the curriculum), knowledge of learners (e.g., knowing what teaching and learning strategies work for each student), and knowledge of educational contexts (Shulman, 1986, 1987).

In the same line, Hawley and Valli (1999) suggested that teacher CPD experiences should be teacher-directed and long-term in order to help teachers develop and recreate their role as educators (Bell \& Gilbert, 1994, Qablan, Mansour, Alshamrani, Aldahmash \& Sabbah, 2015). Such opportunities should be designed to enhance teachers' inquiry experiences (Darling-Hammond, Hyler, \& Gardner, 2017; Darling-Hammond, Wei, Andree, Richardson, \& Orphanos, 2009), encourage teachers to practice, reflect on, and review innovative instructional techniques in a collegial and real classroom environment (Bell \& Gilbert, 1994; Flick, Keys, Westbrook, Crawford, \& Carnes, 1997).

For the case of science education, stakeholders have designed CPD programs to address the above-mentioned criteria to enhance science teachers' content knowledge, pedagogies, and experience using inquiry. However, most of those programs were evaluated to be ineffective because of their short-term duration (Darling-Hammond, Hyler, \& Gardner, 2017; Darling-Hammond, Wei, Andree, Richardson, \& Orphanos, 2009; Supovitz and Turner, 2000). The duration of CPD programs is considered to play a critical role. For example, Supovitz and Turner (2000) found that the programs with durations of less than 80 hours were not effective in sparking change in teacher's practices.

(C) 2019 by the authors; licensee Modestum Ltd., UK. This article is an open access article distributed under the terms and conditions of the Creative Commons Attribution License (http://creativecommons.org/licenses/by/4.0/). \ahmadgablan@hotmail.com (*Correspondence) 


\section{Contribution of this paper to the literature}

- Regardless of the quality and duration of a PD program, teachers will continue to encounter technical, cultural or political barriers when implementing a new instructional approach. Supporting teachers is the key to alleviate their barriers.

- Exposing teachers to diverse instructional practices only seems to be insufficient to change their beliefs. Teachers need to see new practices working in classroom contexts and share and reflect with their colleagues on how to improve the implementation of the new practices.

- Formative assessment is an excellent tool to offer constructive feedback on the effectiveness of the newly implemented practices for designer, teachers and students.

This conclusion has also been assured by Cohen and Hill (1998) study of mathematics teachers involved in CPD programs.

Taking the aforementioned ideas into consideration, both Queen Rania Teacher Academy (QRTA) in Jordan and Teachers' College of Columbia University Middle East Research Center in Jordan (CUMERC) engaged in a partnership to enhance the quality of education in Jordanian public schools. Utilizing the fund from both Jordan Ministry of Planning and United States Agency for International Development (USAID), the partnership has developed and demonstrated a new model of high quality CPD for Jordanian teachers.

The partnership utilized school networks (e.g., Hopkins, 2003; Penuel \& Riel, 2007) as a model for providing CPD experiences for teams of teachers, schools' principals and education supervisors. Each network of schools is subject-specific and focused on the improvement of instruction.

The science school networks model (OECD, 2003; Penuel \& Riel, 2007) is informed by two theories; one is a general theory about adult learning and effective professional development and the second is a theory about the implementation of new practices (Darling-Hammond, et al., 2009; Desimone, 2009; Hattie, 2009). The theory holds that over time the norms of collaboration to improve practice will spread in a school, from the teachers in the initial targeted subject to teachers in other subject areas. Each network is composed of around 20 schools drawn from the same geographic region to support access to periodic PD sessions and to encourage collaboration across schools in the same region. Each school is expected to encourage the participation of a group of science teachers who teach the same subject. The goal is to train around 100 teachers in each cohort during the duration of the program (3 years).

\section{THE SCHOOL SCIENCE NETWORK}

The school science network was developed to help in-service science teachers implement inquiry-based learning strategies in their science instruction. The aim is to help them learn ways to design and implement inquiry-based science lessons to make their instruction more effective. Teachers are learning to use the "5E Instructional Model" for designing inquiry-oriented lessons, which consists of five phases of learning; Engagement, Exploration, Explanation, Elaboration, and Evaluation. Science teachers also learn the "Five Features of Inquiry" which describe what students should be doing in inquiry-oriented classrooms. These five features and related instructional strategies are helping teachers make the shift towards student centered instruction. In inquiry-oriented lessons, students learn to value evidence in developing and elaborating their own explanations for observed phenomena and to address scientific questions. They learn to evaluate their explanations by comparing them to the possible alternatives and to communicate and justify their reasoning. Teachers are learning instructional strategies supportive of the five features.

Over three years, teachers are exposed to 6 subject specific 3-days workshops, in the first workshop, teachers learn the five features of inquiry, during the second and the third workshop, participants learn the 5E instructional model and how to plan and implement inquiry based lessons in the classroom, in the fourth workshop, teachers learn how to use formative assessment to inform their teaching, in the fifth workshop, they learn how to use scientific argumentation to strengthen their students' learning of science, and in the last workshop, they learn strategies to support each other in the school through forming Professional Learning Communities (PLCs) and collaborate with neighboring schools as well. Throughout the program, teachers also learn a range of classroom teaching strategies (i.e., Poster session, Exit ticket, Point of most significance) that connect between classroom management, instruction and assessment to model how inquiry can be implemented in the science classroom.

\section{PURPOSE OF THE STUDY}

This study aimed at assessing the impact of science network's activities on teachers' instructional practices by identifying the successes, challenge and ways to sustain the exemplary inquiry instructional practices in the 
classroom. The idea is to analyze participating science teachers' reflections on a three-year journey of professional development program through answering the following questions:

(1) What successes do science teachers accomplished while participating in the professional development network?

(2) What challenges do they encounter while implementing inquiry-based instruction in their classrooms?

(3) Ways to sustain inquiry science teaching \& learning practices in the Classroom?

To answer these questions, a qualitative research methodology was utilized to guide the overall data collection and analysis. This type of research methodology suits the nature of the research problem that demands a thorough understanding of a social phenomenon from the actor's own perspective (Taylor \& Bogdan, 1998).

\section{METHODOLOGY}

\section{Context of the Study}

QRTA has created several cohorts of science teachers in the country. The third cohort was established in the northern part of Jordan and consisted of 30 schools with 60 participants (15 male and 45 female science teachers). Each school is a house of more than 1,000 student and 40-60 teachers.

The network consists of three inter-related major activities; 8 subject specific face to face workshops, 4 network support meetings, and several network school visits (Qablan, 2016). The duration of the program is 3 years, where teachers received one or two workshops in a semester followed by a network's meeting and several school visits.

Through the Project, participating teachers attend a series of intensive, content-specific three-day workshops over the course of a two years. They also attend Network meetings, conducted by program staff and educational supervisors at schools, the purpose of these meetings is to allow participants to learn from each other and share their successes and challenges in implementing some of the instructional strategies introduced during workshops. Project staff also visit participating schools to support use and refinement of workshop strategies through structured classroom observations, feedback and discussions with trainee teachers.

\section{Research Participants}

Participants of this study consisted of 18 in-service science teachers ( 8 males and 10 females) who agreed to participate in the study from the total number of cohort 3 science network participants. The classroom size of each participating teacher is around 40 students and the teaching load of each teacher ranges from 18-25 session per week. Each participant holds a bachelor's degree in one of the four science fields and teaches either general science for 6, 7, and 8 grades or a specialty subject (Biology, Chemistry, Geology, and Physics) for high school students. The teaching experience of each participant teacher ranges from 6-10 years. Prior to their participation in the CPD program, those teachers had limited knowledge about inquiry and ways to implement it in their science classrooms as they graduated from faculties of sciences but not education. In other words, they were not trained to become teachers prior to starting their teaching profession.

\section{Procedure}

This study is an interpretive analysis of learning for the 18 science teachers participated in cohort 3 QRTA science network, utilizing qualitative data. The author was the lead trainer in the program and acted as a "participant observer" in this study. The primary sources of data included participants' self-reflection form and field notes that were taken throughout the duration of the program.

Self-Reflection form: This form was part of the design of the training program. The form included questions such as: How has the way you teach science changed over the past 3 years? What do you do less of now? What do you do more of now? How have your changes affected student learning? How do you know this? How did you do this? What steps did you take? Each participant was asked to prepare his/her reflection form and submit it at the end of the program.

Field Notes: The lead trainer of the network, who is the author of this study, observed the participating teachers throughout the duration of the program and made sure to collect data to answer the research questions addressed in this study. Field notes included actions taken by teachers, the discussions that they had with their colleagues in the network, and their perceived levels of engagement in the network's activities. Field notes also included 2 classroom observations for each participant in order to see the instructional practices that were implemented in the science classroom that covers all science subjects (Biology, Physics, Geology, and Chemistry). Each of these observations lasted for 50 minutes. All notes were gathered, documented, and analyzed throughout the duration of the program. 


\section{Data Analysis}

Qualitative data from the self reflection, classroom observations in the form of field notes were analyzed throughout the duration of the study (Bogden \& Biklen, 1998). All collected data were analyzed in two major stages: open and focused coding (Emerson, Fretz, \& Shaw, 1995).

In open coding, each data source was carefully read to identify the main ideas suggested by each participant and the and categorize them into emerging themes. During this stage, the author inserted his own reflecting memos on each of the suggested idea and them. In the focused coding, data were further analyzed in the light of the ideas and themes previously identified in the open coding stage. All coded data were then combined for further analysis and write up (Bogdan \& Biklen, 1998).

In order to establish the validity of analyzed data, the author shared his findings with all participants in order to make sure that his interpretations were accurate and reflected each participant's thoughts and reflections.

\section{FINDINGS}

\section{Teacher Accomplished Successes}

Most participating teachers reported making a change in the level of interaction inside their science classrooms. Nearly all teachers $(91 \%)$ agreed that they had noticed an increased level of interaction and students' participation in the classroom due to the implementation of several classroom teaching techniques they learned in the program. Examples of these techniques are "think-pair-share", "I think, we think", and "Round robin". These techniques and several other students-based teaching and assessment techniques have been modeled during the workshops and teachers had several opportunities to reflect on using them in their teaching.

More than $77 \%$ of teachers also reported that they noticed a development in the quality of their students' assignments as a result of enhancing students' engagement and motivation in the science activities. Around $23 \%$ of teachers reported that students have shown a higher level of motivation in the science classroom as well as demonstrated thoughtful explanations of several science phenomena that they learned. Teachers also commented that the implementation of many hands-on science activities as well as interactive teaching techniques have enhanced students' engagements and excitements to learn science. According to teachers, such higher level of motivation resulted into enhancing students' scores in science tests.

In addition to that, $14 \%$ of teachers reported that the training enabled them to become skillful in managing their classroom's time and leverage teachers' capability to allocate more time for difficult science topics and better respond to their students' learning needs. Only, $5 \%$ of participating teachers indicated that their students became more skillful in posing thoughtful questions in the science classroom, which indicates a higher level of understanding and engagement in the learning of science.

Teachers attributed these successes to each part of the CPD program. The analysis of their observations and informal discussions with the researcher showed that what had helped them the most was their engagement in the interactive workshops and how each workshop modeled the way science teaching could be performed. Moreover, participants also commented that they benefited from the supported provided by both the trainers and from their colleagues who participated in the PLCs.

\section{Challenges Faced while Implementing Inquiry-based Instruction in the Classroom}

Despite the several successes that participated teachers reported, they also noted several challenges that face their implementation of what they learned in their classrooms. Almost half of the participants reported that the lack of laboratory equipment at schools is the biggest challenge for them to implement hands-on science activities. They argued that science is different than other subjects as it requires special preparation and equipment to allow students to design and run their science experiments.

Another serious challenge that teachers reported is students' weakness in Mathematics. Around 36\% of teachers argued that their students lack basic knowledge and skills in Mathematics that enable them to do some simple calculations in science (i.e., analyze data). This weakness forces teachers to allocate some of their classroom teaching time to review the needed mathematical skills with their students and encourage them to use those skills in the science classroom. In addition to students' weakness in Mathematics, $18 \%$ of teachers mentioned that their students find learning some science concepts difficult. This students' weakness also forces teachers to dedicate more time for students to learn and understand those concepts, which in turns results into not covering the whole curriculum at the end of the semester as well as deterring teachers from devoting sufficient time for hands-on inquiry science learning. 
Teachers also complained about the thick science curricula that they need to cover and the limited time that they have. Nine percent $(9 \%)$ of participants ranked this challenge third among all of the challenges that they faced. Thick science curricula become further problematic to teachers when their students don't have the needed previous knowledge to learn new science concepts.

Another serious challenge that teachers documented is students' weakness in language. Nine percent of participating teachers reported that some of their students are weak in reading and writing which keeps them behind, comparing to their classmates. Students' weakness in languages has become a recent challenge for Jordanian students due to several factors, some of these factors are policy related and others are financial related.

These challenges became visible to participating science teachers due to their attempts to engage their students in diverse science tasks and lessons that require students to pose inquiry questions, design an experimental design to test their questions, collect and analyze data and reach conclusions. Without engaging students in these highlevel thinking practices, teachers would not be able to figure out the challenges that their students have that the way to resolve them.

\section{Ways to Sustain Inquiry Science Teaching \& Learning practices in the Classroom}

A third component of the self-reflection form was dedicated to report ways to sustain inquiry-based science teaching in schools. Most participants (91\%) recommended that teachers need to implement multiple classroom teaching and learning strategies and techniques based on their suitability to the teaching tasks (Qablan \& DeBaz, 2015). QRTA science training program introduced and modeled several classroom techniques for teachers to use in their teaching. These techniques are designed to facilitate hands-on students' activities and encourage students' participation. Examples of these techniques are "I think, We think", "I used to think, but now I know" and several others. Teachers reported that the use of these techniques has helped them teach their lessons and assess their students' learning at the same time. They also mentioned that these techniques were most welcome by students as they helped them get easily engaged in their learning tasks.

Another important recommendation that $68 \%$ of participants cited is the use of the $5 \mathrm{E}$ instructional model to design learning experiences for students. As they mentioned, the five stages of this model help teachers design specific interactive learning tasks and activities for students. Using this model, teachers become aware of ways to engage their students in the intended learning tasks, suggest focus inquiry questions to lead students' explorative activities, lead students' analysis and interpretations of the data they collected during the exploration stage, think of ways to expand students' understanding of what they learned and try to apply their knowledge and understanding in different contexts and contribute in solving several real life problems and challenges, and design several stations to assess their students' learning throughout the lesson as well as at the end of their learning journey.

The 5E instructional model has also helped teachers manage their teaching time, almost 59\% of teachers reported that the use of the $5 \mathrm{E}$ instructional model enabled them to manage their teaching time and identify what parts of the lesson need more time and what parts require less. The 5E learning model also enables teachers to be adaptive and responsive to the learning needs of their students and diversify the teaching approaches that they use to engage students in the learning activities.

Around $45 \%$ of teachers suggested using several science visualizations and simulations in their teaching. Examples of these visualizations are videos, models, MoE Eduwave online learning platform simulations. They argue that these visualizations support students understanding of scientific concepts and facilitate the application of knowledge and skills for problem solving. Visualizations can also stimulate considerable students' interest and engagement with the topic they study.

Teachers also suggested implementing several diagnostic and formative assessment techniques to identify students' prior knowledge and learning needs. Examples of these techniques are "Round robin", "Point of most significance", "Point of most muddiness" and others. As they mentioned, the use of these techniques that help teachers identify students' prior knowledge before they begin teaching the lesson. They also help students monitor their learning and figure out points that requires more attention.

To address students' weakness in Mathematics and languages, around 32\% of teachers suggested collaborating with both Math and languages teachers to address students' weakness in both subjects and help students learn science easily. Working with teachers of both subjects also help science teachers prepare suitable enrichment and treatment plans to help students overcome their Math and language difficulties that prevent them from learning science appropriately. 


\section{DISCUSSION AND IMPLICATIONS}

Teachers' evaluation of their professional training experiences showed that they have significantly benefited from the program. They became more skillful in engaging their students in the learning activities, more capable to manage their teaching tasks, and more confident about integrating their learned new reformed practices in their instructional practices. However, changing teachers' instructional practices is not something that can be accomplished without barriers. Many factors interfere with teachers when they begin the process of implementing the new instructional practices in the teaching. As Gess-Newsome (2001) stressed in her review of the research on professional development of science teachers, change involves "choosing to relinquish safe and familiar practices for the new and uncertain" (p. 94). Current research findings have identified some of the barriers that teachers may encounter when implementing a new instructional approach, such as inquiry in their contexts. These barriers are categorized as Anderson (1996) mentioned into technical, cultural and political barriers. The following paragraphs will discuss those barriers in detail.

\section{Impact of Technical Barriers}

This dimension includes laboratory and classroom environment, time limitation, and thick science curricula. These barriers, as participants in this study mentioned, limit teachers from implementing inquiry-based science instruction in their teaching. Keys and Bryan (2000) argued that inquiry instruction demands certain technical and logistical preparations (i.e., laboratory equipment) to facilitate conducting inquiry activities. The lack of equipment and lengthy science curricula that participating teachers in this study encountered, made it difficult for them to implement inquiry and other instructional strategies that they gained from the program. Such technical barriers make teachers feel that their teaching is ineffective, as Darling-Hammond (1995) explained, "Many teachers are forced to learn only to cope instead of teach effectively and this can be a very stressful experience". On the other hand, if the teacher has the needed technical support, their efforts will be more likely to be successful.

\section{Impact of Cultural Barriers}

Some participating science teachers in the program seem not to buy into the use of reformed instructional practices presented in the program due to a cultural barrier that is related to their teaching beliefs. Beliefs have been identified to play a significant role in shaping and reshaping teachers' instructional practices. For example, Gess-Newsome (2003) argued that 'the nature of beliefs held by teachers may ultimately make the difference in the success or failure of the current wave of reform" (p. 11). Keys and Bryan (2001) also commented that both teacher's beliefs regarding student learning and science teacher's role have a profound impact on instruction, "substantially affecting planning, teaching and assessment" (p. 636).

Several science educators and professional development providers have emphasized that in order to alter teachers' beliefs and their instructional practices, teachers need to go through several professional and real-life experiences to practice and experience reformed science teaching practices in their own classroom context (GessNewsome, 2003; Loucks-Horsely, Hewson, Love, \& Stiles, 1998). Although this program has engaged participating science teachers in several experiences to learn how to implement these practices in their classrooms, but the program did not mainly intend to alter their pedagogical beliefs. Exposing teachers to diverse instructional practices only seems to be insufficient to change their beliefs. Teachers need more time to see these practices working in classroom contexts and share and reflect with their colleagues on how to improve the implementation of these practices. Therefore, this study suggests that in order for this program to be more effective and help teachers change their teaching beliefs, more time should be dedicated to focus on targeting teachers' beliefs and experiences by providing teachers with opportunities to challenge their beliefs and see the merit of adopting reformed-based instruction, including the use of inquiry. Examples of practices that help teachers rethink their beliefs are; involving them in planning sessions, asking them to conduct need surveys to ensure that the new practices or strategies are well aligned with what they want (Joyce, McNair, Diaz, \& McKibbin, 1976).

Despite the importance of these procedures, they rarely alter teachers' attitudes significantly or elicit teachers' commitment (Jones \& Hayes, 1980). Guskey (2002) suggests an alternative model of CPD that argues that a significant change in teachers' attitudes and beliefs occurs primarily after they gain evidence of improvements in student learning as a result of implementing a new instructional approach. So, the point of Guskey's model is that it is not the professional development that changes teachers' attitudes and beliefs but the experience of successful implementation of a new instructional practice.

\section{Impact of Political Barriers}

Political barriers seem to be the toughest for teachers to control. Teachers in this study encountered several political barriers such as the time of classroom session, teacher teaching load, and non-teaching responsibilities of 
teachers. Political barriers have several consequences on both school and educational directorate administration, as the need to support teachers is apparent in this study. This need, however, should exceed providing teacher with professional development experiences. Teachers should have a school mentor teacher, observe other science teachers' colleagues, and have continued support from school principal and educational governorate administrators. Teachers' instructional choices should also be supported, such as teaching science by inquiry versus using science class time to sharpen students' reading and Mathematical skills. Physical resources such as space, class time, equipment, budget for consumable materials are all key to effective inquiry science instruction. Many teachers in this study lack basic resources needed to implement the changes they desired in their settings.

Lack of time for collaboration at school was also a serious political barrier that was mentioned by participating teachers in this study. They mentioned that they did not have opportunities to plan for their teaching with their science colleagues who teach the same grade level. Several studies have stressed the importance of allocating more time for teachers to plan for their teaching together and test the use of different instructional strategies in their classrooms. (Fullan, 2001; Loucks-Horsley et al., 1998). Findings in this study also have shown the importance of collaboration in the success of implementing instructional reform efforts. Some teachers sacrificed their lunch and break times to meet and work with their colleagues. This sacrifice, however, puts an added stress on teachers who may need to stay after work hours to make up their delayed work tasks.

Although the program administrators have requested the MoE and school principals to allocate more free time for participating teachers to enable them to work together, but that request was not approved due to shortage in science teachers. However, the training program has built-in free times for teachers to work together and share their experiences with each other.

\section{IMPLICATIONS FOR PROFESSIONAL DEVELOPMENT}

\section{Recognizing that Change is Difficult but a Gradual Process}

Learning to be proficient at implementing something new requires both time and effort. Becoming more confident in implementing reformed teaching strategies (i.e., inquiry), is likely to require more work from teachers, especially at the beginning. This additional work requires more time and significantly add to teachers' workload, and makes teachers feel overwhelmed.

Furthermore, change seems to increase the level of anxiety and can be very threatening for most of the people. That anxiety makes teachers more reluctant to adopt the new practices or procedures unless they are confident that they will work (Lortie, 1975). Trying something new means taking a risk of failure. Therefore, teachers seem reluctant to implement their learned reformed practice unless they find support from their surrounding environment in order to minimize the risk that they are taking. The QRTA, science network program offered its participating teachers several opportunities to share their experiences and reflect on their challenges through establishing PLCs in schools and between schools. Those professional structures, as shown in the findings sections, have significantly not only helped teachers transfer their learning to their classrooms but also influence teachers of other subjects.

\section{Providing Continued Assessment and Feedback}

In order to sustain reformed new practice (i.e., inquiry science teaching), involved teachers need to receive continuous assessment and feedback on the impacts of their efforts (Qablan et al., 2015). It is well known that impactiful practices are likely to be repeated over and over while those that are unsuccessful tend to disappear. Similarly, new teaching practices will be accepted and reserved by teachers when they are perceived as increasing teachers' effectiveness (Bredeson, Fruth, \& Kasten, 1983; Guskey, 1989; Huberman, 1992). New practices are expected to disappear in the absence of any evidence of their positive impact. Therefore, informing teachers and providing them with specific feedback on the impact of their newly implemented practices is essential to the success of sustaining their efforts.

Formative assessment is an excellent tool to offer constructive feedback on the effectiveness of the newly implemented practices for both teachers and students. It provides teachers with evidence of the impacts of their efforts and illustrate the changes made in students' learning. According to Guskey (1997), formative assessments can be used to increase teachers' effectiveness.

To address that concern, the QRTA science network implemented several formative assessment practices and collected both qualitative and quantitative feedback from participants to adjust both the design and the implementation of the program. Furthermore, the program dedicated a whole 3-day workshop on formative assessment to enable teachers to use it to inform their teaching practices. That advantage of using formative 
assessment in teaching has clearly appeared both in participants' reflection forms as well as in the conducted classroom observations.

\section{Provide Sustained Follow-Up and Support}

Guaranteeing significant change in teachers' attitudes and beliefs before implementing the new program will ensure the impact of the program's new practices. However, such change occurs mainly after implementation takes place and there is proofs of improved student learning, sustainable follow-up and support following the program's training that is even more crucial.

Providing trained teachers with the needed support is essential to continue their improvements. Support provided to teachers who participated in the science network has Cleary allowed teachers to manage their anxiety of their failures. It also provided them with the encouragement and motivation they needed to overcome their encountered challenges along the way (Airasian, 1987; Huberman \& Crandall, 1983).

\section{LIMITATIONS AND FUTURE RESEARCH}

The study focused on assessing the impact of QRTA science network's activities on teachers' instructional practices. However, the study did not consider the impact of other networks such as Mathematics, English, Leadership and Arabic on teachers' instructional practices. Future studies could address this need by conducting similar qualitative analysis to assess the impact of other networks on teachers' practices. More studies also needed to further investigate how science network staff adapt the network's professional activities based on participating teachers' beliefs and attitudes.

\section{ACKNOWLEDGEMENT}

This study is funded by the Hashemite University, Jordan.

\section{REFERENCES}

Airasian, P. W. (1987). State mandated testing and educational reform: context and consequences, American Journal of Education, 95(3), 393-412. https:/ / doi.org/10.1086/444312

Anderson, R.D. (1996). Study of curriculum reform. Vol.1: Findings and conclusions. Studies of Educational Reform. (ERIC Document Reproduction Service No. ED 397535)

Bell, B., \& Gilbert, J. (1994). Teacher development as professional, personal, and social development. Teaching and Teacher Education, 10(5), 483-497. https:/ / doi.org/10.1016/0742-051X(94)90002-7

Bogdan, R., \& Biklen, S. (1998). Qualitative research for education: an introduction to theory and methods, 3rd ed. Allyn and Bacon, Needham Heights.

Bredeson, P. V., Fruth, M. J., \& Kasten, K. L. (1983) Organizational incentives and secondary school teaching, Journal or Research and Development in Education, 16(1), 24-42.

Cohen, D. K., \& Hill, H. C. (1998). State policy and classroom performance: Mathematics reform in California. Washington, DC: Consortium for Policy Research in Education. https://doi.org/10.1037/e382832004-001

Darling-Hammond, L., \& McLaughlin, M. (1995). Policies that support professional development in an era of reform. Phi Delta Kappan, 76(8), 597-604.

Darling-Hammond, L., Hyler, M. E., \& Gardner, M. (2017). Effective Teacher Professional Development. Palo Alto, CA: Learning Policy Institute.

Darling-Hammond, L., Wei, R. C., Andree, A., Richardson, N., \& Orphanos, S. (2009). Professional learning in the learning profession. Washington, DC: National Staff Development Council; Desimone, L. M. (2009). Improving impact studies of teachers' professional development: Toward better conceptualizations and measures. Educational researcher, 38(3), 181-199.

Desimone, L. (2009). Improving impact studies of teachers' professional development: Toward better conceptualizations and measures. Educational Researchers, 38(3), 181-199. https:/ / doi.org/10.3102/0013189X08331140

Emerson, R. M., Fretz, R. I., \& Shaw, L.L. (1995). Writing ethnographic fieldnotes. Chicago, IL: The University of Chicago Press. https:/ / doi.org/10.7208/chicago/9780226206851.001.0001

Flick, L., Keys, C. W., Westbrook, S. L., Crawford, B. A., \& Carnes, G. N. (1997). Perspectives on inquiry-oriented teaching practices: Conflict and clarification. Paper presented at the National Association for Research in Science Teaching, Oak Brook, IL. 
Fullan, M. (2001). The new meaning of educational change. New York: Teachers College Press. https:/ / doi.org/10.4324/9780203986561

Gess-Newsome, J. (2001). The professional development of science teachers for science education reform: A review of the research. In. J. Rhoton \& P. Bowers (Eds.), Professional development planning and design. (pp. 91-100), Arlington, VA: NSTA Press.

Gess-Newsome, J. (2003, April). Implications of the definitions of knowledge and beliefs on research and practice in science teacher education. Paper presented at the annual meeting of the National Association for Research in Science Teaching, Philadelphia, PA.

Guskey, T. R. (1989). Attitude and perceptual change in teachers, International Journal of Educational Research, 13(4), 439-453. https:/ / doi.org/10.1016/0883-0355(89)90039-6

Guskey, T. R. (1997). Implementing Mastery Learning, 2nd edn (Belmont, CA, Wadsworth Publishing Company).

Guskey, T. R. (2002). Professional Development and Teacher Change. Teachers and Teaching: theory and practice, 8(3/4), 381-391. https:/ / doi.org/10.1080/135406002100000512

Hattie, J. (2009). Visible learning: A synthesis of over 800 met-analyses relating to achievement. New York: Routledge. https://doi.org/10.4324/9780203887332

Hawley, W., \& Valli, L. (1999). The Essentials of Effective Professional Development: A New Consensus. In L. Darling-Hammond, \& G. Sykes (Eds.), Teaching as the Learning Profession: Handbook of Policy and Practice (pp. 127-150). San Francisco, CA: Jossey-Bass.

Hopkins, D. (2003). Understanding Networks for Innovation in Policy and Practice. In Networks of Innovation: Towards New Models for Managing Schools and Systems, (Schooling for Tomorrow series) Paris.

Huberman, M. (1992) Teacher development and instructional mastery, in: A. Hargreaves \& M. G. Fullan (Eds) Understand Teacher Development (pp. 122-142) (New York, Teachers College Press).

Huberman, M., \& Crandall, D. (1983) People, Policies and Practice: examining the chain of school improvement, Vol. 9, Implications for Action: a study of dissemination efforts supporting school improvement (Andover, MA, The Network Inc.).

Joyce, B., McNair, K. M., Diaz, R., \& McKibbin, M. D. (1976). Interviews: Perceptions of professionals and policy makers. Stanford, CA: Stanford Center for Research and Development in Teaching, Stanford University.

Keys, C. W., \& Bryan, L. A. (2000). Co-constructing inquiry-based science with teachers: Essential research for lasting reform. Journal of Research in Science Teaching, 38(6), 631-645. https:/ / doi.org/10.1002/ tea.1023

Lortie, D. C. (1975). Schoolteacher: a sociological study (Chicago, IL, University of Chicago Press).

Loucks-Horsley, S., Hewson, P., Love, N., \& Stiles, K. (1998) Designing professional development for teachers of mathematics and science. Thousand Oaks, CA: Corwin Press.

OECD. (2003). Networks of innovation: Towards new model for managing schools and systems. Paris. https:/ / doi.org/10.1787/9789264100350-en

Qablan, A., \& DeBaz, T. (2015). Facilitating elementary science teachers' implementation of inquiry-based science teaching. Teacher Development, 19(1), 3-21. https://doi.org/10.1080/13664530.2014.959552

Qablan, A., Mansour, N., Alshamrani, S., Aldahmash, A., \& Sabbah, S. (2015). Ensuring Effective Impact of Continuing Professional Development: Saudi Science Techers' Perspective. Eurasia Journal of Mathematics, Science E Technology Education, 11(3), 619-631. https:/ / doi.org/10.12973/eurasia.2015.1352a

Qablan, A. (2016). Teaching and learning about science practices: Insights and challenges in professional development. Teacher Development, 20(1), 76-91. https:// doi.org/10.1080/13664530.2015.1111929

Penuel, W., \& Riel, M. (2007). The 'New' science of networks and the challenge of school change. Phi Delta Kappan, 88(8), 611-615. https:/ / doi.org/10.1177/003172170708800813

Shulman, L. S. (1986). Those who understand: Knowledge growth in teaching. Educational Researcher, 15(2), 4-14. https://doi.org/10.3102/0013189X015002004

Shulman, L. S. (1987). Knowledge and teaching: Foundations of the new reform. Harvard Educational Review, 57(1), 1-23. https://doi.org/10.17763/haer.57.1.j463w79r56455411

Supovitz, J., \& Turner, H. (2000). The effects of professional development on science teaching practices and classroom culture. Journal of Research in Science Teaching, 37(9), 963-980. https://doi.org/10.1002/10982736(200011)37:9<963::AID-TEA6>3.0.CO;2-0

Taylor, S., \& Bogdan, R. (1998). Introduction to qualitative research methods: a guidebook and resource. NY: Wiley.

\section{http://www.ejmste.com}

